\title{
Malignant migrating partial seizures of infancy
}

INSERM

\section{Source}

INSERM. (1999). Orphanet: an online rare disease and orphan drug data base. Malignant migrating partial seizures of infancy. ORPHA:293181

A rare, genetic, neonatal epilepsy syndrome disease characterized by onset in the first 6 months of life of almost continuous migrating polymorphous focal seizures with corresponding multifocal ictal electroencephalographic discharges, prog ressive deterioration of psychomotor development, and usually early mortality. 